\title{
A cDNA CLONE FOR PROTEIN Z, A MAJOR BARLEY ENDOSPERM ALBUMIN
}

by

\author{
SØREN K. RASMUSSEN, H. ESTEBAN HOPP") and ANDERS BRANDT \\ Department of Physiology, Carlsberg Laboratory \\ Gamle Carlsberg Vej 10, DK-2500 Copenhagen Valby \\ and
}

IB SVENDSEN

Department of Chemistry, Carlsberg Laboratory

Gamle Carlsberg Vej 10, DK-2500 Copenhagen Valby

and

JØRN HEJGAARD

Department of Biochemistry and Nutrition

Technical University of Denmark, B.224, DK-2800 Lyngby

"Fellow of the Consejo National de Investigationes Científicas y Téchnicas, present address: Departamento de Genética INTA, CC25, 1712 Castelar, República Argentina.

Keywords: Lysine-rich storage protein, in vitro protein synthesis, mRNA, N-terminal amino acid sequence, nucleotide sequence, gene family

An 18 residue amino terminal sequence of the barley endosperm protein $\mathrm{Z}$ polypeptide is presented. In vitro translation of barley endosperm mRNA and subsequent immunoaffinity isolation using protein $Z$ antibodies identified two major protein $Z$ precursor polypeptides of M.W. 44,000 and 46,000 among the translation products. Partial nucleotide sequence analysis identified a cDNA clone to encode the amino terminal portion of protein $\mathrm{Z}$. Messenger RNA sequences 1,800 nucleotides in length, sufficient to code for the protein $Z$ precursor polypeptides, were detected by hybridization to the protein $Z \mathrm{cDNA}$ probe. Hybridization of the probe to restriction endonuclease fragments of barley nuclear DNA suggests, that protein $\mathrm{Z}$ is encoded by a small multigene family.

Abbreviations: $\mathrm{cDNA}=$ DNA complementary to $\mathrm{mRNA}$; $\mathrm{kbp}=$ kilo basepair; SDS-PAGE = sodium dodecyl sulphate polyacrylamide gel electrophoresis; $\mathrm{SSC}=0.15 \mathrm{M}$-sodium chloride, $0.015 \mathrm{M}$-sodium citrate. 


\section{INTRODUCTION}

The storage protein of the barley endosperm, hordein, is poor in amino acids essential for the nutrition of monogastric animals. It has been suggested that the nutritional quality of the barley grain could be improved by increasing the synthesis of lysine rich polypeptides at the expense of hordein (16). By molecular cloning of cDNA encoding hordein polypeptides, it has been possible to analyse in detail the structure and the expression of hordein genes in the barley endosperm $(3,6,9)$. In addition, we would like to study the organization and expression of the genes encoding lysine-rich polypeptides, in order to investigate at the molecular level the possibility to change the nutritional quality of the barley grain.

The salt soluble protein fraction of the barley endosperm contain several lysine rich polypeptides, e.g. two protease inhibitors, $\beta$-amylase and protein $Z(5)$. The two protease inhibitors and $\beta$-amylase have been shown to be synthesized on the endoplasmic reticulum of the endosperm cell (8), whereas the site of synthesis of protein $Z$ remains to be determined. Protein $\mathrm{Z}$ is a major component of the albumin fraction of the barley grain and is coded for by a locus on the barley chromosome 4 (11). In the present study we present the amino terminal sequence of protein $Z$, identify a cDNA clone encoding this portion of the protein $Z$ polypeptide and provide hints of the organization of the protein $Z$ genes in the barley genome. The cDNA is used in the accompanying paper to study the expression of protein $Z$ genes in developing barley endosperms (3).

\section{MATERIALS AND METHODS}

\subsection{Chemicals}

All chemicals used for the amino acid sequence determination were from Rathburn, Scotland, except ethylacetate which was obtained from Merck, FRG. N-cetyl-N,N,N-trimethylammoniumbromide was obtained from Merck, FRG. Restriction endonucleases, Eco RI, Hind III and Pst I, DNA polymerase I, the Klenow fragment, T4-DNA ligase and hybridization primer (M13 system) d(C-A-C-A-A-T-TC-C-A-C-A-C-A-A-C) were obtained from Boehringer, FRG. Synthetic M13 specific

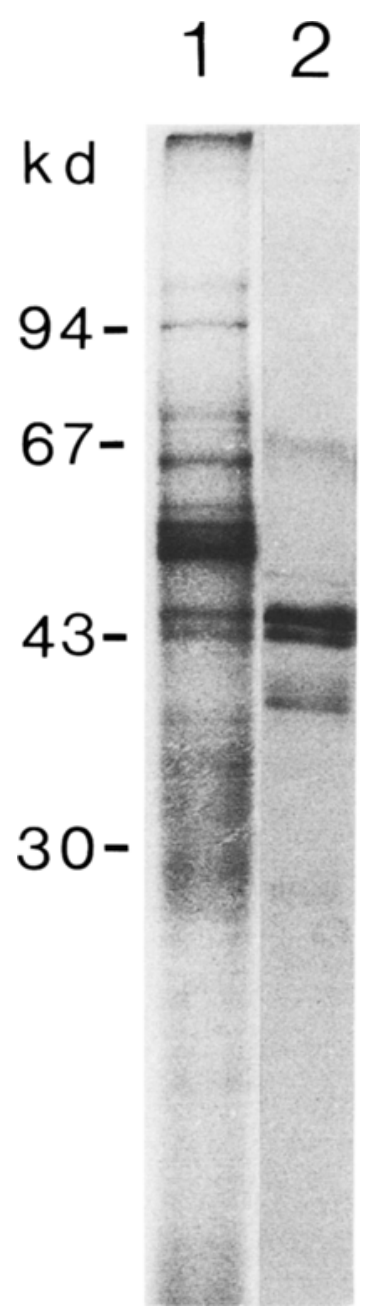

Figure 1. Immunoaffinity isolation of protein $\mathrm{Z}$ precursor polypeptides.

Total in vitro translation products (track 1) and immunoaffinity isolated polypeptides employing monospecific protein $Z$ antibodies (track 2), were separated by SDS-PAGE and the polypeptides visualized by fluorography. Molecular weight standards are indicated to the left.

primer d(T-C-A-C-G-A-C-G-T-T-G-T) was from Collaborative Research, USA. ${ }^{32} \mathrm{P}-\mathrm{dATP}$ and Gene Screen Hybridisation Transfer Membranes were from New England Nuclear, USA. ${ }^{35} \mathrm{~S}$-methionine was from Amersham, UK. Nitrocellulose filters were from Schleicher \& Schuell, FRG. 


pc paz1-1 - CCC CTG AAG GTG GAT TTG GTG GAT TTT GTC GCG AAT CAC
Protein $Z$ - pro leu lys val asp leu val asp phe val ala asn his
$\mathrm{H}_{2} \mathrm{~N}-$ pro leu lys val asp leu val asp phe val ala asn his

CCT TTC CTC TTC CTT ATT CGG GAA GAC ATT GCC GGT-
pro phe leu phe leu ile arg glu asp ile ala gly-
pro phe leu phe leu

Figure 2. Partial nucleotide sequence of pc paz $1-1$ coding for the amino-terminal portion of a protein $Z$ polypeptide.

The amino acid sequence predicted by the genetic code is shown below the nucleotide sequence and compared to the amino-terminal protein $\mathrm{Z}$ sequence established by automated Edman degradation.

\subsection{Plant material}

Barley plants (Hordeum vulgare, L.) cv. Bomi and cv. Carlsberg II were grown, and 20 days old endosperms isolated as previously described (2).

\subsection{Amino acid sequence determination}

Protein $\mathrm{Z}$ was purified from barley seeds as described in (4). The amino terminal sequence determination was done on the combined fractions nos. 45-46 and 48-50 from the final DEAESephadex anion exchange step, using a Beckmann model $830 \mathrm{C}$ automatic liquid phase sequencer, with the programme 129974 supplied by the company. $0.1 \mathrm{M}-\mathrm{N}, \mathrm{N}, \mathrm{N}^{\prime}, \mathrm{N}^{\prime}$ tetrakis (2-hydroxyethyl) ethylenediamine was used instead of Quadrol, and ethylacetate containing $15 \%$ propanol as recommended by BEGG and MORGAN (1). Identification of phenylthiohydantoin amino acids was performed by high pressure liquid chromatography on a reverse phase (RP-18) column $4.6 \times 250 \mathrm{~mm}$ packed with $\mu$ Bondapak $\mathrm{C} 18,10 \mu$ in particle size using a Hewlett-Packard HPLC chromatograph model 1084B. For elution a linear gradient from

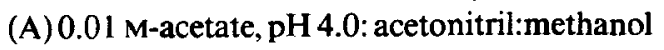
$(9: 1: 1)$ to $(B)$ methanol was used.

\subsection{Barley DNA and RNA isolation}

Total DNA was isolated from leaves of 8 days old etiolated seedlings as described by MURRAY and THOMPSON (10). Instead of using octanol, 3-methyl-1-butanol was used in the chloroform extraction. Ultracentifugation in $\mathrm{CsCl}$ and recovery of the DNA was as in (6). The RNA was isolated from endosperms as described in $(2,6)$.

\subsection{In vitro translations}

The in vitro translations of barley messenger RNA and the immunoaffinity isolation of the in vitro synthesized polypeptides by monospecific rabbit antibodies raised against protein $Z$ (4) was carried out as described in $(3,8)$.

\subsection{Nucleotide sequence determination}

The isolated cDNA fragment was partially sequenced by the dideoxy method as described in $(12,14)$.

\subsection{DNA and RNA transfers and hybridisations \\ DNA was separated by agarose gel electropho- resis and blotted to nitrocellulose filters as de- scribed by SOUTHERN (15). Hybridisation in}




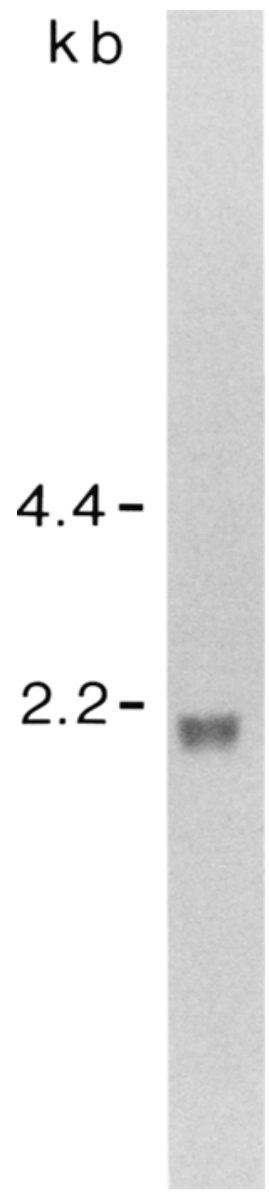

Figure 3. Detection of mRNA encoding protein $Z$ polypeptides.

Carlsberg II endosperm RNA were separated by electrophoresis on a agarose gel containing formaldehyde, transferred to nitrocellulose filter and hybridized to ${ }^{32} \mathrm{P}$-labelled pc paz1-1. RNA complementary to the probe was detected by autoradiography. The apparent molecular size was estimated by comparison with barley ribosomal RNAs as markers.

$2 \times S S C$ at $68^{\circ} \mathrm{C}$ as described in (6) using the protein $\mathrm{ZcDNA}$ fragment labelled by nicktranslation as a probe (13). RNA was electrophoretically separated on agarose gels containing formaldehyde, blotted to Gene Screen membranes and hybridised as described in (6). Single stranded M13 phage containing the strand complementary to protein $Z$ messenger RNA, was radioactively labelled according to $\mathrm{HU}$ and MessiNG (7), and used as a probe.

\section{RESULTS AND DISCUSSION}

The autoradiogram of total in vitro translation products of mRNA isolated from immature Bomi barley endosperms is shown in Figure 1, track 1 . Among the translation products are two polypeptides of M.W. 46,000 and 44,000. By immunoaffinity isolation using a protein $\mathrm{Z}$ antibody preparation these were identified as protein $\mathrm{Z}$ polypeptides (Figure 1, track 2 ). Native protein $\mathrm{Z}$ is composed of a number of polypeptides differing in isoelectric points with molecular weights around 40,000 (4). The polypeptides displayed in Figure 1, track 2 might therefore represent precursor polypeptides of protein $Z$. The presence of lower molecular weight polypeptides in the track might be due to prematurely terminated polypeptides containing the antibody binding site. Thus translation of barley endosperm mRNA shows that protein $\mathrm{Z}$ mRNA is abundantly present in the immature endosperm. The presence of two different molecular sized protein $\mathrm{Z}$ precursor polypeptides among the translation products indicate, that at least two different mRNAs encoding protein $\mathrm{Z}$ are present in the endosperm mRNA population, since no processing is thought to occur in the rabbit reticulocyte lysate translation system. We therefore expect at least two different protein $\mathrm{Z}$ genes in the barley genome.

In our analysis of a barley endosperm cDNA clone collection (6) we found a 360 nucleotide long cDNA hybridizing strongly to endosperm mRNA. Partial nucleotide sequence analysis of this cDNA resulted in the sequence depicted in Figure 2. The derived amino acid sequence is shown below the nucleotide sequence and compared to the amino terminal amino acid sequence obtained by automatic Edman degradation of a purified protein $\mathrm{Z}$ polypeptide. Complete identity between the 18 amino-terminal residues of the protein sequence and the protein sequence deduced from the nucleotide sequence show that this cDNA (pc paz1-1) encodes the amino-terminal portion of a protein $\mathrm{Z}$ polypeptide.

In order to determine the size of the mRNA coding for protein Z, RNA from Carlsberg II endosperms was isolated, separated by electrophoresis on an agarose gel containing formaldehyde and transferred to a nitrocellulose filter. 


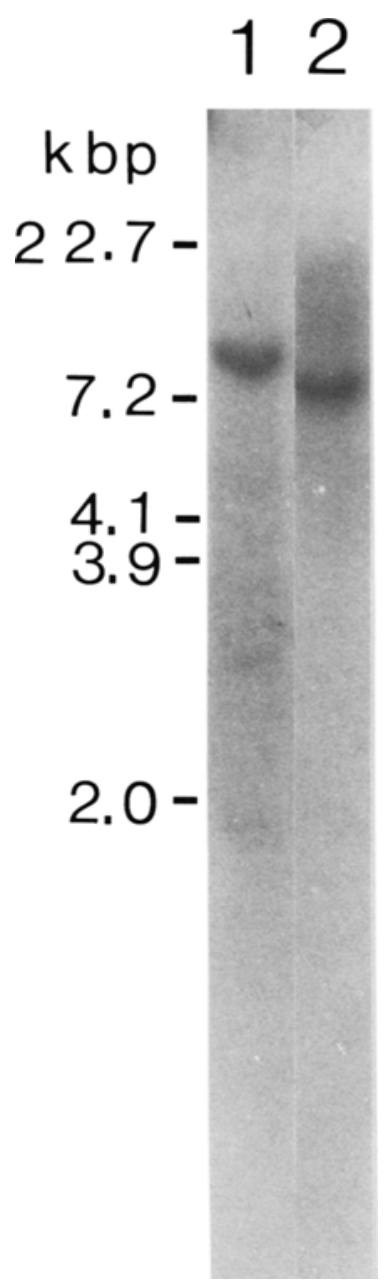

Figure 4. Protein $Z$ genes in the nuclear DNA from Carlsberg Il barley.

Leaf DNA was cleaved with the restriction endonucleases Hind III (track 1) and Eco RI (track 2), separated by agarose gel electrophoresis, transferred to nitrocellulose filters and hybridized to ${ }^{32} \mathrm{P}$-labelled pc pazl-1. The hybridizing fragments were detected by autoradiography. The sizes of the fragments were estimated using Hind III restriction endonuclease fragments of $\lambda \mathrm{WES} / \lambda \mathrm{B}$ as markers.

Hybridization was carried out with the radioactively labelled pc paz1-1 clone. The endosperm contained RNA sequences with an estimated size of 1,800 nucleotides hybridizing to the probe (Figure 3). The size of the protein $Z$ precursor polypeptides $(46,000$ to 44,000 , Figure 1) will require $1,400-1,300$ nucleotides in the coding region of the mRNA thus leaving 500 - 400 nucleotides for the 5' and 3' non-coding regions including a poly $A$ tail.

DNA from Carlsberg II barley leaves was isolated and digested with Hind III and Eco RI restriction endonucleases. The resulting fragments were separated by agarose gel electrophoresis, transferred to nitrocellulose filters and hybridized to the ${ }^{32} \mathrm{P}$-labelled pc paz $1-1$ plasmid at conditions of medium stringency. One strongly hybridizing Hind III restriction fragment of $9.5 \mathrm{kbp}$ and two weakly hybridizing fragments of 2.9 and $1.8 \mathrm{kbp}$ were detected (Figure 4, track 1). Only one strongly hybridizing Eco RI restriction fragment of $8 \mathrm{kbp}$ was found (track 2). We tentatively estimate the strongly hybridizing Hind III and Eco RI fragments to represent 5 copies and the weakly hybridizing Hind III fragments to represent 1 copy each of the gene per haploid genome. Thus the Hind III and Eco RI restriction pattern indicate that protein $\mathrm{Z}$ is coded for by a small multigene family.

Further studies will be aimed at determining the primary structure of protein $\mathrm{Z}$ genes and at elucidating the site of synthesis and deposition of protein $\mathrm{Z}$ polypeptides in the barley endosperm.

\section{ACKNOWLEDGEMENT}

This work was supported by the Biomolecular Engineering Programme of the Commission of the European Communities with contract No. GB 1-4-024-DK to Professor D. vON WETTSTEIN.

\section{REFERENCES}

1. BEGG.G. \& F. MORGaN: A non-volatile buffer with improved performance in automated protein sequencing. FEBS Lett. 66, 243-245 (1976)

2. BRANDT, A.\& J. INGVERSEN: Isolation and translation of hordein messenger RNA from wild type and mutant endosperms in barley. Carlsberg Res. Commun. 43, 451-469 (1978)

3. GIESE. H. \& H.E. HOPP: Influence of nitrogen nutrition on the amount of hordein, protein $Z$ and $\beta$-amylase messenger RNA in developing endosperms of barley. Carlsberg Res. Commun. 49, 365-383 (1984)

4. HejgaARd, J.: Purification and properties of pro- 
tein Z - a major albumin of barley endosperm. Physiol. Plant. 54, 174-182 (1982)

5. HejgaARd, J.\& S. BoIseN: High-lysine proteins in Hiproly barley breeding: Identification, nutritional significance and new screening methods. Hereditas 93, 311-320 (1980)

6. HoPP, H.E., S.K. RaSMUSSEN \& A. BRANDT: Organization and transcription of $B 1$ hordein genes in high lysine mutants of barley. Carlsberg Res. Commun. 48, 201-216 (1983)

7. Hu, N. \& J. Messing: The making of strand-specific M13 probes. Gene 17, $271-277$ (1982)

8. Jonassen, I., J. IngVersen \& A. Brandt: Synthesis of SPII albumin, $\beta$-amylase and chymotrypsin inhibitor Cl-1 on polysomes from the endosplasmic reticulum of barley endosperm. Carlsberg Res. Commun. 46, 175-181 (1981)

9. Kreiss, M., P. R. Shewry, B. G. Forde, S. RahMAN \& B. MIFLIN: Molecular analysis of a mutation conferring the high-lysine phenotype on the grain of barley (Hordeum vulgare). Cell 34, 161167 (1983)

10. Murray, M. G. \& W. F. Thompson: Rapid isolation of high molecular weight plant DNA. Nucl. Acids Res. 8, 4321-4325 (1980)
11. Nielsen, G.. H. Johansen, J. Jensen \& J. HejGAARD: Localization on barley chromosome 4 of genes coding for $\beta$-amylase (Bmyl) and protein $\mathrm{Z}$ (Paz1). Barley Genet. Newslett. 13, 55-57 (1983)

12. Rasmussen, S.K.. H.E. HoPP \& A. BrandT: Nucleotide sequences of $\mathrm{CDNA}$ clones for $\mathrm{B} 1$ hordein polypeptides. Carlsberg Res. Commun. 48, 187199 (1983)

13. Rigby, P.W., M. Dieckmann, C. Rhodes \& P. BERG: Labelling deoxyribonucleic acid to high specific activity in vitro by nick translation with DNA polymerase I. J. Mol. Biol. 113, 237-251 (1977)

14. Sanger, F, S. Nicklen \& A.R. Coulson: DNA sequencing with chain-terminating inhibitors. Proc. Natl. Acad. Sci. USA 74, 5463-5467 (1977)

15. SOUTHERN, E.M.: Detection of specific sequences among DNA fragments separated by gel electrophoresis. J. Mol. Biol. 98, 503-517 (1975)

16. WetTSTEIN, D. von: Genetic engeneering in the adaption of plants to evolving human needs. Experientia $39,687-713(1983)$ 